\title{
HASIL TELAAH JURNAL PENINGKATAN HASIL BELAJAR LOMPAT JAUH GAYA JONGKOK DENGAN MENGGUNAKAN REKAMAN VISUAL
}

\author{
Nama : Raudha Fashli Nugraha \\ Kelas : X MIA 1
}

Materi yang diajarkan dalam PJOK terdiri atas olahraga permainan dan olahraga atletik, namun jenis olahraga atletik kurang diminati siswa.Atletik merupakan salah satu cabang olah-raga yang memiliki banyak nomor dalam suatu perlombaan, salah satu nomor yang diperlombakan tersebut adalah pada nomor lompat jauh. Hingga saat ini, ada tiga gaya yang dikenal dalam lompat jauh, yakni

1. gaya jongkok

2. gaya menggantung

3. gaya berjalan di udara

Berdasarkan hasil observasi dalam pembelajaran jasmani di SMPN Satap Manuru banyak siswa yang terlihat kurang semangat dalam aktivitas pembelajaran lompat jauh.

Hal ini disebabkan oleh guru bidang studi yang hanya menyampaikan materi pembelajaran dengan media buku paket dari sekolah, papan tulis, dan kapur tulis untuk berimajinasi dari media yang digambarkan di depan tanpa penalaran logis yang tinggi. Metode pembelajaran berpengaruh terhadap efektivitas belajar siswa yang dilihat dari proses belajar siswa yang kurang berminat dan kurang aktif.

Upaya menungkatkan prestasi lompat jauh perlu dilakukan dengan media visual yang menampilakan gerak lompat jauh secara utuh, bertahap, dapat diperlambat dan diputar berulang-ulang sehingga lebih nudah diamati. Media visual berupa rekaman dengan tampilan yang dapat diperlambat atau diputar ulang menjadikan siswa mudah mengamati detail teknik lompat jauh.

Schmidt (1991) memberikan gambaran yang lebih jelas bahwa pembelajaran gerak adalah serangkaian proses yang dihubungkan dengan latihan atau pengalaman yang mengarah pada perubaban-perubahan yang relatif permanen dalam kemampuan seseorang untuk menam-pilkan gerakan-gerakan yang terampil.

Salah satu teori belajar gerak yaitu model Fitts dan Posner (1997). Model ini menunjukkan bahwa peserta didik harus melewati tiga tahapan yang berbeda. Tahapan ini ditentukan oleh proses pembelajaran yaitu *tahap kognitif *tahap asosiatif 
*tahap automatisasi

Kemampuan siswa dalam atletik terlihat dari kelincahan, kelenturan, gaya, dan teknik lompat jauh yang diterapkan. Penilaian atas tiga aspek utama yaitu pengetahuan, sikap dan perilaku, dan psikomotor (keterampilan motorik dan kebugaran). Secara umum, media pembelajaran mempumyai kegumaan untuk mengatasi berbagai hambatan, antara lain hambatan komumikasi, keterbatasan belajar, sikap siswa yang pasif, berbeda. Media pembelajaran audio visual tersebut dapat berupa audio rekaman yang dikeluarkan oleh Asosiasi Federasi Atletik Internasional (IAAF).

Penelitian ini adalah penelitian tindakan kelas. Penelitian tindakan kelas memiliki banyak model. Pada penelitian ini, model yang digunakan adalah model Kemmis dan McTaggart. Model ini menggunakan empat komponen penelitian dalam setiap langkahnya yaitu:

1. Perencanaan

2. tindakan,

3. Observasi

4. Refleksi

Pada tahap merencanakan tindakan (planing), peneliti melihat kemungkinan tindakan yang akan dilakukan dalam pembelajaran melahi rekaman visual. Observasi dilakukan sejak awal persiapan hingga berlangsungnya praktik lompat jauh gaya jangkok sampai selesai.

Hal-hal yang akan diobseravasi yaitu

1. Kelincahan

2. Kelenturan

3. penguasaan teknik jongkok

4. hasil lompatan

Refleksi dilakukan setelah mempelajari hasil post-test siklus 2 serta hasil pengamatan selama proses tindakan kelas dilangsungkan.

\section{Kriteria penilaian tentang hasil lompat}

$>3,4$ Sangat Baik

$2,8 \leq 3,4$ Baik

$2,2 \leq 2,8$ Cukup

$<2,2$ Kurang

Xi $($ Rerata ideal $)=1 / 2($ skor maksimum ideal + skor minimum ideal $)$

Sbi (Simpangan baku ideal)= 1/6 (sko maksimum ideal-skor minimum ideal) $X=$ Skor empiris 
Skor makimum 4

Skor minimm 1

$X i=2,5$

$\mathrm{Sbi}=0,5$

\section{SIKLUS 1}

Siklus 1 terdiri atas tiga pertemuan. Setiap pertemuan terbagi dalam empat tahap pembelajaran yaitu:
A. perencanaan
B. pelaksanaan tindakan
C. observasi
D. refleksi

-)Pada pertemuan pertama, pembelajaran dimulai dengan melakukan persiapan, baik mempersiapkan siswa, mempersiapkan tempat latihan dan mempersiapkan alat

-)Pada pertemuan kedua, pembelajaran dimulai dengan melakukan persiapan, baik mempersiapkan siswa, mempersiapkan video rekaman lompat jauh gava jongkok, dan mempersiapkan alat dan tempat untuk praktik lompatan.

-)Pada pertemuan ketiga, setelah melihat rekaman visual, guru meminta siswa untuk mengerjakan soal tes akhir tentang penguasaan teknik lompat jauh gaya jongkok. Guru melakukan tes akhir berupa praktik lompat jauh gava jongkok.

\section{SIKLUS 2}

dilaksanakan sebanyak tiga pertemuan.

-) Pada pertemuan pertama, pembelajaran dimulai dengan melakukan persiapan, baik mempersiapkan siswa, mempersiapkan video rekaman lampat jauh gaya jongkok dengan gambar gerak yang sudah diperlambat, dan mempersiapkan alat dan tempat untuk praktik lompatan

-) Pada pertemuan kedua, pembelajaran dimulai dengam melakukan persiapan, baik mempersiapkan siswa, mempersiapkan video rekaman lompat jauh gaya jongkok dengan gambar gerak yang sudah diperlambat, dan mempersiapkan alat dan tempat untuk praktik lompatan.

-) Pada pertemuan ketiga, siswa menyimak langkah-langkah lompat jauh gaya jongkok yang disampaikan guru. Selanjutnya guru meminta siswa untuk mengerjakan soal tes akhir guna mengetahui penguasaan siswa tentang teknik lompat jauh gaya jongkok. 


\section{Hasil Penelitian}

Berdasarkan hasil penelitian dan pembahasan tentang peningkatan hasil belajar lompat

jauh gaya jongkok dengan menggunakan rekaman visual pada siswa kelas IX SMP Satap Manuru dapat ditarik kesimpulan bahwa rekaman visual dapat meningkatkan hasil belajar

siswa. Peningkatan ini dibuktikan dengan pengetahuan, penguasaan teknik,dan hasil lompatan siswa. Pengetahuan tentang lompat jauh gaya jongkok terus meningkat dengan nilai rata-rata 62,79 pada awal tindakan menjadi 68,95 pada siklus 1 dan meningkat menjadi 76,50 pada siklus 2. Penguasaan teknik sebelum mendapatkan tindakan berupa rekaman gambar hanya pada skor 2,33. Setelah mendapatkan tindakan pada siklus 1 naik menjadi 2,96. Setelah mendapatkan tindakan pada siklus 2 naik menjadi 3,36. Hasil lompatan juga me-ningkat. Rata -rata lompatan yang berhasil dilakukan sebelum tindakan kelas yaitu $203,3 \mathrm{~cm}$, sedangkan hasil lompatan setelah siklus 1 mencapai $232,37 \mathrm{~cm}$. Setelah akhir siklus 2, hasil lompatan meningkat mencapai $244,1 \mathrm{~cm}$. Dengan demikian, terjadi peningkatan hasil belajar lompat jauh dengan capaian nilai pengetahuan ratarata di atas KKM 70, aspek penguasaan teknik mencapai kategori baik, dan hasil lompatan mencapai lebih dari $240 \mathrm{~cm}$.

\section{Kesimpulan}

rekaman visual dapat meningkatkan hasil belajar siswa Peningkatan ini dibuktikan dengan pengetahuan, penguasaan teknik, dan hasil lompatan siswa yang terus menimgkat 